\title{
A Survey-Based Education Needs Analysis of Employment Support Programs for Hospitality Undergraduate Students
}

\author{
Tae-Kyun $\mathrm{Na}^{1}$ (D) and Sun-Ho Lee ${ }^{2, *}$ \\ 1 Department of Culinary Arts, Doowon Technical University, Paju 10838, Korea; food@doowon.ac.kr \\ 2 Department of Foodservice and Culinary Arts, Honam University, Gwangju 62399, Korea \\ * Correspondence: sundalnim@hanmail.net
}

Citation: Na, Tae-Kyun, and Sun-Ho Lee. 2021. A Survey-Based Education Needs Analysis of Employment Support Programs for Hospitality Undergraduate Students. Social Sciences 10: 103. https://doi.org/ 10.3390/socsci10030103

Academic Editors: Karen Arnold and Kathy Chau Rohn

Received: 8 February 2021

Accepted: 16 March 2021

Published: 18 March 2021

Publisher's Note: MDPI stays neutral with regard to jurisdictional claims in published maps and institutional affiliations.

Copyright: (c) 2021 by the authors. Licensee MDPI, Basel, Switzerland. This article is an open access article distributed under the terms and conditions of the Creative Commons Attribution (CC BY) license (https:/ / creativecommons.org/licenses/by/ $4.0 /)$.

\begin{abstract}
The purpose of this study was to analyze employment support programs that should be prioritized for hospitality undergraduate students in Korea, given the lack of such programs that are tailored to students' majors. Using a questionnaire survey, we measured the differences between the perceived importance and the perceived current level of availability of employment support programs recognized by 384 students enrolled in hospitality-related courses. Both 2-year and 4-year majors recognized employment information support, certificate programs, career seminars, overseas training support, field practice programs, and overseas employment support as high-priority programs. Individual career counseling, mentoring, and industry-academic cooperation courses were the highest priority programs that should be applied to 2-year majors, but in the case of 4-year majors, these three programs were found to be relatively well supported by universities. Mock interviews, language programs, and employment-related courses were the top priority programs to support 4-year majors. However, 2-year majors perceived that mock interviews and language programs were of low importance, and there was little difference between the importance and current level of employment-related courses. It is necessary to develop support programs from the learner's point of view by accurately grasping the needs for employment support programs.
\end{abstract}

Keywords: Borich needs analysis; COVID-19 impacts; current level; employment support program; higher education; hospitality college students

\section{Introduction}

The rate of completion of tertiary education among young people (25-34 years old) in Korea was 69.8\% in 2019, ranking second among the Organization for Economic Cooperation and Development (OECD) countries (KEDI Korean Educational Development Institute). However, there are many cases of Korean students entering university by deciding their major according to their social atmosphere or grades rather than considering their interests, talents, and abilities. After entering university, they are unable to adjust to their major and give up their studies. Those that do graduate experience difficulties in finding employment (Han and Hwang 2019). In fact, from 2009 to 2019, the average OECD youth unemployment rate declined by $4.4 \%$, while the youth unemployment rate in Korea increased $0.9 \%$ (KERI Korea Economic Research Institute). In particular, the employment status of hospitality undergraduate students is more seriously affected than that of students in other industries due to the COVID-19 pandemic. According to Statistics Korea's report on employment trends in August 2020, the employment rate in the lodging and restaurant industries fell by $7.2 \%$ compared to the same month the previous year (KOSTAT Statistics Korea).

In this situation, universities are making every effort to solve the problem of youth unemployment by recognizing the responsibility of students to advance into society and by developing various employment support programs to improve student career development and employment capabilities (Lee and You 2019; Youn and You 2015). However, 
looking at the research results of Choi (2020) and An (2018), who analyzed the operational status of and satisfaction with employment support programs, universities were not able to provide various employment support programs for students, and students' participation and satisfaction were generally low. In addition, it was found that there were no employment support programs that were beneficial to female students and 2-3-year college students, who could have a relative disadvantage in employment. For employment support programs to have a practical effect, it is important to review the effectiveness from the supplier's perspective, but it is also necessary to accurately grasp the demands for employment programs from the perspective of learners participating in these programs (Oh et al. 2014; Jung et al. 2018).

In addition, employment support programs operated by universities have a limitation in that they do not reflect the characteristics of their major (Lee and You 2019; An 2018). In other words, it is necessary to develop an employment support program according to the major from the learner's point of view to improve the practical ability and employment capability of the major. In particular, in the case of the hospitality industry major, which is predicted to show relatively poor performance in the labor market compared to other majors due to the COVID-19 pandemic, a discussion on the development of employment support programs tailored to the major is needed. However, studies on the needs of learners or the effectiveness of employment support programs for hospitality industry-related majors have only analyzed the effectiveness of single employment support programs such as language training and internship (Wang et al. 2014; Tsai et al. 2017), mentoring (Scerri et al. 2020), and major qualification (Deale and Schoffstall 2015; Moreo et al. 2018). There is no research on which programs should be developed and supported first for hospitality majors. In addition, hospitality-related majors in Korea are offered at both 2-3-year and 4 -year universities, and students take the same qualification exam and are employed in the same field. However, since 2-3-year college students have to decide and prepare their own careers in a short period of 2-3 years, unlike in regular 4-year colleges, students have many difficulties in transitioning to the world of work after graduation.

Therefore, this study aimed to analyze education needs by investigating the importance and current level of various employment support programs operated by universities as perceived by hospitality undergraduate students enrolled in 2-3-year-and 4-year universities. Through this, the aim was to suggest which employment support programs should be operated with the highest priority to improve the career planning and employment capabilities of hospitality undergraduate students.

\subsection{Theoretical Background}

\subsubsection{Hospitality Education and Employment}

The positive outlook for the development of the hospitality industry in Korea and the concomitant job creation effect is leading to the expansion of the establishment of departments related to the hospitality industry in regular higher education institutions (Kim et al. 2019). According to Korea Educational Statistics Service (KESS Korean Educational Statistics Service), as of 2020, approximately 270,000 people are majoring in hospitality in vocational colleges and universities. The name of the major has also been subdivided and expanded from the existing tourism management and hotel management majors into various fields such as aviation, conventions, culture, leisure, food service, and culinary arts (Kim 2018; Ahn and Yim 2018).

However, according to some studies, the graduates of hospitality-related departments do not have a high preference for employment in the hospitality industry after participating in internship programs, or they completely leave the hospitality industry (Lee and Chao 2013; Zopiatis and Theocharous 2013), and it is judged that a sufficient number of jobs are not being created at the level that students want. In addition, even though it is difficult to find a job, graduates leave after working for three to five years in the hospitality industry due to relatively low wages and long working hours, and the high turnover rate is a major problem in the industry (Kim 2019; Zampoukos and Ioannides 2011). Moreover, as of 
2020, countries around the world are implementing measures such as business shutdowns, travel bans, self-isolation, and teleworking to prevent the spread of COVID-19, causing enormous damage to the aviation, travel, hotel, and food service industries (Choi and Kim 2020; Kaushik and Guleria 2020). In addition, even if the recovery of the tourism industry becomes apparent over the next one to two years, it is still unclear whether it will be able to recover fully (Kim 2020). However, if universities support hospitality undergraduate students with a variety of programs that can improve the knowledge, skills, and attitudes required by the hospitality industry in the post-COVID-19 era, there will be a dependable supply of human resources when the labor demand in the hospitality industry recovers.

\subsubsection{Employment Support Programs}

An employment support program is defined as a program that supports the process of reinforcing the abilities of university students as jobseekers and in choosing a career path (An 2018; Seo and Kim 2016). Three recent studies (Jung et al. 2018; Shin et al. 2014; Chun et al. 2019) were done in Korea about the types of employment support programs presented in the Graduates Occupational Mobility Survey (GOMS), which is being conducted by the Korea Employment Information Service with the aim of constructing empirical data on labor market entry and transition after graduation. The types of employment support programs suggested by GOMS consist of eight types, namely, career/employment-related subjects, work experience programs (including internships), occupational psychology tests such as personality tests, on-campus career fairs, career-related individual and group counseling programs, interview skills and résumé writing programs, employment camps, and corporate employment information sessions (Lee et al. 2020).

However, the employment support programs presented in GOMS do not include all employment support programs for hospitality majors. In other words, employment support programs that are of high importance for hospitality majors should be included. To this end, studies related to career and employment for hospitality majors are as follows. First, studies by Deale and Schoffstall (2015) and Moreo et al. (2018) showed that it is worthwhile for hospitality majors to obtain certificates before entering the industry. Ahn et al. (2018) found that obtaining a professional certificate has a positive effect on employment performance. Second, Scerri et al. (2020) found that through industry mentoring in the hospitality industry, student mentees can build knowledge and skills and develop networking opportunities to build confidence. Kim et al. (2017) found that mentoring had a positive effect on the career decisions of hospitality majors. Third, participation in contests by food and beverage majors or culinary arts majors was found to have a positive effect on career and employment-related variables (Lee and Hwang 2019; Kim and Chung 2018). Fourth, as globalization continues, overseas employment or overseas internship programs are actively applied in the hospitality industry (Busby and Gibson 2010; Aquino et al. 2017). Jun (2013) argued that international internships and overseas employment in hospitality education should be strengthened by operating an internationalization program to cultivate global talent. In addition, the foreign language communication ability of hospitality industry workers is regarded as an essential factor for efficient work performance (Min 2008; Kim et al. 2020). In this way, this study aimed to measure the importance and current level of employment support programs recognized by hospitality majors by including employment support programs such as obtaining certificates, participating in competitions, language studies, and overseas employment in the employment support programs used by GOMS.

\subsubsection{Education Needs Analysis}

Needs analysis is to find a problem by investigating the gap between "what is" and "what should be," and to determine priorities in order to find an optimal solution (Oh et al. 
2014). Borich's needs analysis is currently the most widely used method for prioritization in needs analysis, and the calculation formula is as follows (Borich 1980).

$$
\text { Borich }=\frac{\sum(\text { Importance }- \text { Current level })}{\text { Number of respondent }} \times \text { Mean of importance }
$$

This method allows one to determine the relative ranking by weighting the overall average of importance to the difference between the importance and the current level, and then checking the ranking of the calculated result values. Borich's needs analysis is evaluated positively in that it overcomes the simple difference comparison between the importance and the current level, which is the limit of the t-test, but it is a method that requires attention in interpretation in that if both the importance and difference between importance and current level are low but the difference is large, they can be classified as priorities compared to the elements with both high importance and achievement and not a large difference (Song 2020). In addition, Cho (2009) pointed out that when there are many analysis items, there is a limitation in that it is not possible to consider which ranking should be selected as the target of education.

In order to complement the limitations of Borich's needs analysis, many studies (Cho 2009; Bae and Yoon 2015; Lim et al. 2020) suggest priorities by using the needs analysis of Borich and the Locus for Focus model of Mink et al. (1991) in combination. The Locus for Focus model has the advantage of being able to easily display results visually by dividing the average value of importance on the horizontal axis and the average value of the difference between importance and current level on the vertical axis, as shown in Figure 1 (Cho 2009). In this model, the first quadrant, which indicates high importance and a high degree of discrepancy between the importance and the current level, is the highest priority and can be viewed as the area that needs to be improved most urgently (Park et al. 2020). In this study, Borich's needs analysis and the Locus for Focus model were used to determine the highest priority in employment support programs for hospitality undergraduate students.

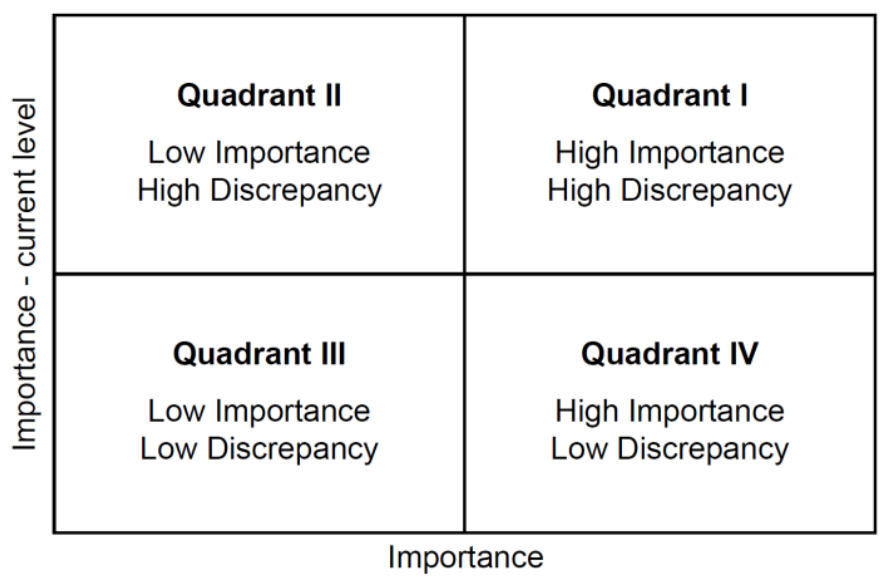

Figure 1. The Locus for Focus Model.

\section{Materials and Methods}

\subsection{Variables and Instruments}

To analyze the priority of employment support programs required by hospitality undergraduate students, rather than focusing on the employment support programs operated by some universities, the study sought to include all of the employment support programs generally supported by universities. To this end, the eight employment support programs presented by GOMS were further subdivided, and a total of 23 employment support programs were formed by adding programs that were found to affect the career and employment of hospitality undergraduate students, such as certification acquisition 
support, language programs, and support for participation in contests. The types and characteristics of the 23 employment support programs are shown in Table 1. Since the names and support methods of the programs are different for each university, the names and characteristics of the programs were reviewed by three experts in charge of job support-related work in universities before the survey, and then some contents were modified before use. Each employment support program item used a Likert 5-point scale to measure its importance by asking students how important they think it is for career and employment and the current level of support for that program. In addition, to understand the demographic characteristics of the survey subjects, gender, department, and school system were configured as nominal scales.

Table 1. Types and characteristics of employment support programs used in the research.

\begin{tabular}{|c|c|c|}
\hline & Program & Characteristic \\
\hline 1 & Career-related courses & Courses to improve ability to decide and design one's own career path \\
\hline 2 & Employment-related courses & $\begin{array}{c}\text { Courses aimed at strengthening job competency through planned } \\
\text { employment preparation }\end{array}$ \\
\hline 3 & Industry-academic cooperation courses & $\begin{array}{c}\text { Courses to improve problem-solving skills, such as capstone design, or } \\
\text { courses operated through agreements with industries }\end{array}$ \\
\hline 4 & Field practice programs & $\begin{array}{c}\text { A program that supports job performance in industry for a certain period of } \\
\text { time }\end{array}$ \\
\hline 5 & Industrial site tour programs & One-time support program to visit industries in the major field \\
\hline 6 & Occupational psychology tests & $\begin{array}{l}\text { A screening program that helps choose career fields and professions that are } \\
\text { more suitable for individual characteristics }\end{array}$ \\
\hline 7 & Career path special lecture programs & $\begin{array}{l}\text { One-time lectures for lower grades that provide information related to career } \\
\text { paths in major fields }\end{array}$ \\
\hline 8 & Employment special lecture programs & $\begin{array}{c}\text { One-time lectures for higher grades that provide information related to } \\
\text { employment in major fields }\end{array}$ \\
\hline 9 & Career fairs & $\begin{array}{l}\text { A program in which various companies outside the school provide job } \\
\text { seekers with recruitment information, on-site support, and interviews }\end{array}$ \\
\hline 10 & Career seminars & $\begin{array}{l}\text { A program that introduces recruitment procedures and jobs to students } \\
\text { within the university by companies that wish to hire talent }\end{array}$ \\
\hline 11 & Individual career counseling & $\begin{array}{l}\text { Counseling program conducted by counselors and clients on a one-to-one } \\
\text { basis in relation to individual career }\end{array}$ \\
\hline 12 & Group career counseling & $\begin{array}{c}\text { Counseling program conducted by one or two counselors and multiple } \\
\text { clients in relation to individual careers }\end{array}$ \\
\hline 13 & Résumé writing support & 1:1 customized résumé and self-introduction writing coaching by experts \\
\hline 14 & Mock interviews & $\begin{array}{c}\text { A program that supports experiencing an interview in advance in a situation } \\
\text { similar to an actual job interview }\end{array}$ \\
\hline 15 & Employment camps & $\begin{array}{l}\text { A program that is run outside the university to improve employment mind } \\
\text { and job search skills through a two-day or three-day course }\end{array}$ \\
\hline 16 & Employment information support & Providing various information related to employment online or offline \\
\hline 17 & Competition support & Support program for participation in competitions in major fields \\
\hline 18 & Overseas employment support & $\begin{array}{c}\text { Pre-education and employment information support for overseas } \\
\text { employment }\end{array}$ \\
\hline 19 & Overseas training support & $\begin{array}{l}\text { Programs to support a stay abroad for a set period of time for education } \\
\text { purposes }\end{array}$ \\
\hline 20 & Language programs & $\begin{array}{l}\text { Support for language training at home and abroad to improve language } \\
\text { skills }\end{array}$ \\
\hline 21 & Certificate programs & Program to support the acquisition of certificates in major fields \\
\hline 22 & Job club support & $\begin{array}{l}\text { Support program for groups voluntarily formed by students with similar } \\
\text { employment goals to prepare for employment }\end{array}$ \\
\hline 23 & Mentoring & $\begin{array}{l}\text { A program that helps mentees' (students') careers and employment through } \\
\text { mentors such as industry workers or seniors in their major fields }\end{array}$ \\
\hline
\end{tabular}




\subsection{Research Subjects \\ 2.2.1. Participants}

A questionnaire survey was conducted with university students enrolled in a major that included hotels or food services. Considering that there will be a difference in the current level of employment support programs depending on the size of the university, the application budget, and the school system, the questionnaire survey was conducted only for majors enrolled in four 2-year universities and four 4-year universities participating in the Leaders in Industry-college (university) Cooperation project, which is supported by the Ministry of Education to solve employment difficulties and corporate labor shortages. In addition, as higher-year college students had access to more employment support programs in college than lower-year students, only students enrolled in the graduation semester were included in the survey. A total of 384 students participated in the survey. Among the total respondents, 206 (53.6\%) were men and 178 (46.4\%) were women. As for the school system, 185 (48.2\%) were 2-year university students, and $199(51.8 \%)$ were 4 -year university students. In the case of majors, 213 (55.5\%) were hotel-related majors and $171(44.5 \%)$ were food service-related majors.

\subsubsection{Procedure}

For the survey, before filling out a questionnaire using a survey program provided by Google, prior consent was obtained from the professor of the relevant department, and social network services (SNS) were used to conduct surveys for 15 days, from 16-30 September 2020, only for departments from which permission was received.

\subsection{Analysis Method}

The data collected through the questionnaire were analyzed using the SPSS 18.0 statistical program. Frequency analysis was performed to analyze the demographic characteristics of respondents, and a paired t-test was performed to verify the statistical significance of the average difference between the importance and current level of employment support programs. In addition, the need for employment support programs was calculated based on the needs formula of Borich (1980) using the Excel program, and items corresponding to the first quadrant were derived through the Locus for Focus analysis.

\section{Results}

\subsection{Borich Needs Analysis of 2-year University Students}

Table 2 shows the results of the paired t-test and Borich needs analysis to verify the difference between the importance and current level of employment support programs recognized by 2-year university students.

The differences in importance and current level of the 23 employment support programs were all statistically significant. Among employment support programs, careerrelated courses, occupational psychology tests, and career path special lecture programs showed higher current levels than importance. Looking at the results of the Borich needs analysis, among employment support programs, the need for employment information support (4.17) was the highest, and then, needs were high in the order of individual career counseling (3.87), certificate programs (3.83), career seminars (3.80), and overseas training support (3.56). In contrast, the need for career-related courses (-1.99), career path special lecture programs $(-0.64)$, occupational psychology tests $(-0.51)$, industry field trips $(0.582)$, and employment clubs (0.66) were found to be low.

Figure 2 shows the results of analyzing the priority of employment support programs using the Locus for Focus analysis. The name of the employment support program corresponding to the number in the grid can be identified by the number in the first column of Table 2. Based on the average of the importance of employment support programs recognized by the 2-year university majors (mean $=3.53$ ) and the average of the difference between importance and current level (mean $=0.40)$, nine factors were included in the first quadrant (top right) on the coordinate plane, namely industry-academic cooperation 
courses, field practice programs, career seminars, individual career counseling, employment information support, overseas employment support, overseas training support, certificate programs, and mentoring.

Table 2. Results of paired t-test analysis and Borich needs analysis for 2-year university students.

\begin{tabular}{|c|c|c|c|c|c|c|c|c|}
\hline \multirow{2}{*}{ No. } & \multirow{2}{*}{ Program } & Importance & Current Level & \multirow{2}{*}{ Gap } & \multirow{2}{*}{$\mathbf{t}$} & \multirow{2}{*}{$\mathbf{p}$} & \multirow{2}{*}{$\begin{array}{l}\text { Borich Needs } \\
\text { Score }\end{array}$} & \multirow{2}{*}{ Rank } \\
\hline & & Mean & Mean & & & & & \\
\hline 1 & Career-related courses & $3.04 \pm 0.59$ & $3.69 \pm 0.59$ & -0.65 & -10.59 & 0.000 & -1.99 & 23 \\
\hline 2 & Employment-related courses & $3.14 \pm 0.65$ & $2.83 \pm 0.58$ & 0.31 & 4.96 & 0.000 & 0.98 & 12 \\
\hline 3 & $\begin{array}{l}\text { Industry-academic cooperation } \\
\text { courses }\end{array}$ & $3.53 \pm 0.63$ & $3.13 \pm 0.60$ & 0.40 & 6.51 & 0.000 & 1.41 & 10 \\
\hline 4 & Field practice programs & $4.01 \pm 0.77$ & $3.26 \pm 0.70$ & 0.74 & 9.72 & 0.000 & 2.97 & 6 \\
\hline 5 & Industrial site tour programs & $3.59 \pm 0.67$ & $3.43 \pm 0.65$ & 0.16 & 2.98 & 0.003 & 0.582 & 20 \\
\hline 6 & Occupational psychology tests & $3.06 \pm 0.68$ & $3.23 \pm 0.61$ & -0.17 & -2.69 & 0.008 & -0.51 & 21 \\
\hline 7 & $\begin{array}{c}\text { Career path special lecture } \\
\text { programs }\end{array}$ & $3.18 \pm 0.59$ & $3.38 \pm 0.64$ & -0.20 & -3.43 & 0.001 & -0.64 & 22 \\
\hline 8 & $\begin{array}{c}\text { Employment special lecture } \\
\text { programs }\end{array}$ & $3.69 \pm 0.74$ & $3.43 \pm 0.66$ & 0.26 & 3.73 & 0.000 & 0.98 & 13 \\
\hline 9 & Career fairs & $3.07 \pm 0.62$ & $2.83 \pm 0.61$ & 0.24 & 3.88 & 0.000 & 0.75 & 15 \\
\hline 10 & Career seminars & $3.84 \pm 0.72$ & $2.85 \pm 0.67$ & 0.99 & 14.52 & 0.000 & 3.80 & 4 \\
\hline 11 & Individual career counseling & $4.12 \pm 0.66$ & $3.18 \pm 0.66$ & 0.94 & 14.65 & 0.000 & 3.87 & 2 \\
\hline 12 & Group career counseling & $2.88 \pm 0.60$ & $2.58 \pm 0.70$ & 0.29 & 4.68 & 0.000 & 0.84 & 14 \\
\hline 13 & Résumé writing support & $3.78 \pm 0.83$ & $3.58 \pm 0.60$ & 0.19 & 2.56 & 0.011 & 0.74 & 16 \\
\hline 14 & Mock interviews & $3.36 \pm 0.75$ & $2.93 \pm 0.61$ & 0.43 & 6.20 & 0.000 & 1.43 & 9 \\
\hline 15 & Employment camps & $3.55 \pm 0.74$ & $3.35 \pm 0.73$ & 0.20 & 2.57 & 0.011 & 0.71 & 18 \\
\hline 16 & $\begin{array}{l}\text { Employment information } \\
\text { support }\end{array}$ & $4.02 \pm 0.72$ & $2.98 \pm 0.71$ & 1.04 & 13.87 & 0.000 & 4.17 & 1 \\
\hline 17 & Competition support & $3.88 \pm 0.82$ & $3.69 \pm 0.74$ & 0.19 & 2.925 & 0.004 & 0.71 & 17 \\
\hline 18 & Overseas employment support & $3.53 \pm 0.74$ & $2.75 \pm 0.69$ & 0.78 & 10.42 & 0.000 & 2.75 & 7 \\
\hline 19 & Overseas training support & $3.81 \pm 0.64$ & $2.88 \pm 0.63$ & 0.94 & 15.18 & 0.000 & 3.56 & 5 \\
\hline 20 & Language programs & $3.21 \pm 0.59$ & $2.81 \pm 0.56$ & 0.40 & 6.46 & 0.000 & 1.28 & 11 \\
\hline 21 & Certificate programs & $4.00 \pm 0.67$ & $3.04 \pm 0.66$ & 0.96 & 13.63 & 0.000 & 3.83 & 3 \\
\hline 22 & Job club support & $3.22 \pm 0.67$ & $3.02 \pm 0.58$ & 0.21 & 3.35 & 0.001 & 0.66 & 19 \\
\hline \multirow[t]{2}{*}{23} & Mentoring & $3.65 \pm 0.65$ & $3.12 \pm 0.66$ & 0.54 & 9.246 & 0.000 & 1.96 & 8 \\
\hline & Mean & 3.53 & 3.13 & 0.40 & & & & \\
\hline
\end{tabular}

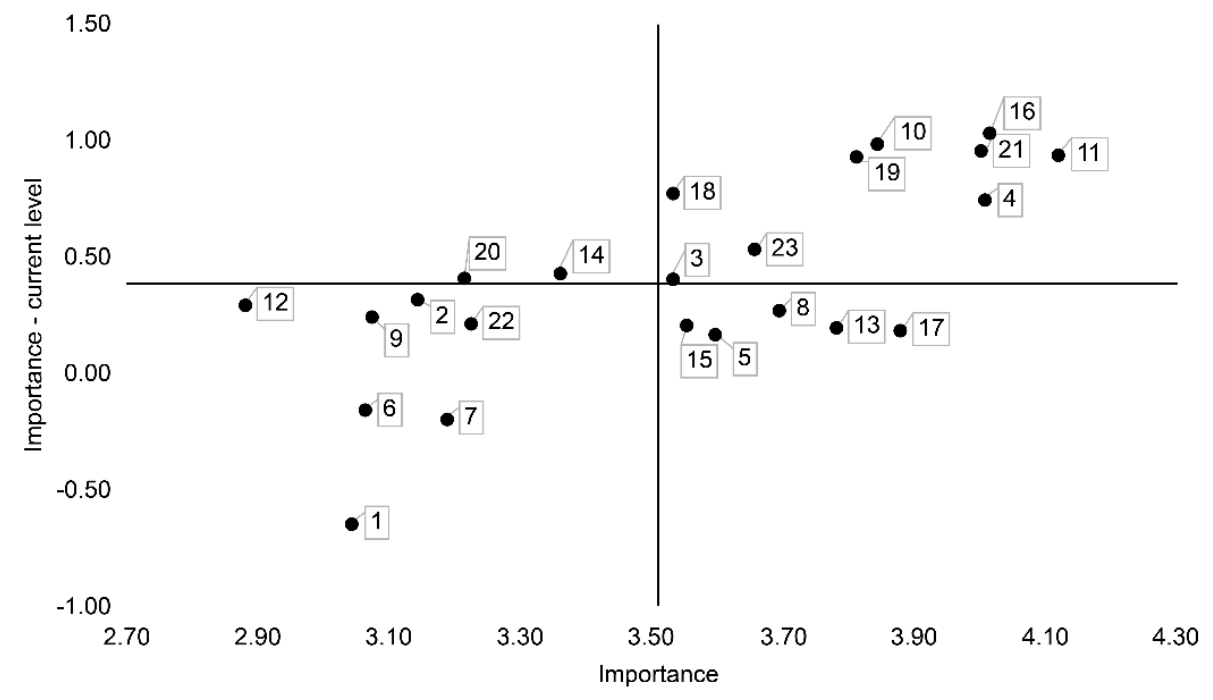

Figure 2. Results of the Locus for Focus Analysis of 2-year University Students. 


\subsection{Borich Needs Analysis of 4-year University Students}

Table 3 shows the results of the paired t-test and Borich needs analysis to verify the difference between the importance and current level of employment support programs recognized by 4-year university students.

Table 3. Results of paired t-test analysis and Borich needs analysis for 4-year university students.

\begin{tabular}{|c|c|c|c|c|c|c|c|c|}
\hline \multirow{2}{*}{ No. } & \multirow{2}{*}{ Program } & Importance & Current Level & \multirow{2}{*}{ Gap } & \multirow[t]{2}{*}{$\mathbf{t}$} & \multirow{2}{*}{$\mathrm{p}$} & \multirow{2}{*}{$\begin{array}{c}\text { Borich Needs } \\
\text { Score }\end{array}$} & \multirow{2}{*}{ Rank } \\
\hline & & Mean & Mean & & & & & \\
\hline 1 & Career-related courses & $3.39 \pm 0.61$ & $3.54 \pm 0.69$ & -0.2 & -2.4 & 0.017 & -0.51 & 22 \\
\hline 2 & Employment-related courses & $3.77 \pm 0.67$ & $2.96 \pm 0.63$ & 0.81 & 12.59 & 0 & 3.05 & 5 \\
\hline 3 & $\begin{array}{l}\text { Industry-academic cooperation } \\
\text { courses }\end{array}$ & $3.68 \pm 0.62$ & $3.34 \pm 0.76$ & 0.34 & 5.19 & 0 & 1.26 & 12 \\
\hline 4 & Field practice programs & $3.99 \pm 0.64$ & $3.10 \pm 0.64$ & 0.89 & 14.74 & 0 & 3.55 & 1 \\
\hline 5 & Industrial site tour programs & $3.48 \pm 0.68$ & $3.33 \pm 0.52$ & 0.15 & 2.72 & 0.007 & 0.52 & 20 \\
\hline 6 & Occupational psychology tests & $3.08 \pm 0.67$ & $3.47 \pm 0.58$ & -0.4 & -6.09 & 0 & -1.22 & 23 \\
\hline 7 & $\begin{array}{c}\text { Career path special lecture } \\
\text { programs }\end{array}$ & $3.53 \pm 0.66$ & $3.65 \pm 0.59$ & -0.1 & -2.23 & 0.027 & -0.41 & 21 \\
\hline 8 & $\begin{array}{c}\text { Employment special lecture } \\
\text { programs }\end{array}$ & $3.62 \pm 0.64$ & $3.38 \pm 0.61$ & 0.25 & 3.95 & 0 & 0.89 & 15 \\
\hline 9 & Career fairs & $3.50 \pm 0.70$ & $3.09 \pm 0.58$ & 0.41 & 6.42 & 0 & 1.44 & 11 \\
\hline 10 & Career seminars & $3.99 \pm 0.61$ & $3.48 \pm 0.59$ & 0.51 & 9.22 & 0 & 2.05 & 9 \\
\hline 11 & Individual career counseling & $3.78 \pm 0.68$ & $3.46 \pm 0.66$ & 0.33 & 5.61 & 0 & 1.24 & 13 \\
\hline 12 & Group career counseling & $3.14 \pm 0.61$ & $2.90 \pm 0.59$ & 0.24 & 3.99 & 0 & 0.74 & 18 \\
\hline 13 & Résumé writing support & $3.47 \pm 0.76$ & $3.26 \pm 0.71$ & 0.22 & 3.2 & 0.002 & 0.75 & 17 \\
\hline 14 & Mock interviews & $3.92 \pm 0.67$ & $3.30 \pm 0.60$ & 0.62 & 9.47 & 0 & 2.45 & 7 \\
\hline 15 & Employment camps & $3.63 \pm 0.63$ & $3.21 \pm 0.77$ & 0.42 & 6.04 & 0 & 1.53 & 10 \\
\hline 16 & $\begin{array}{c}\text { Employment information } \\
\text { support }\end{array}$ & $3.96 \pm 0.70$ & $3.17 \pm 0.67$ & 0.79 & 11.64 & 0 & 3.12 & 4 \\
\hline 17 & Competition support & $3.60 \pm 0.73$ & $3.38 \pm 0.76$ & 0.23 & 3.66 & 0 & 0.81 & 16 \\
\hline 18 & Overseas employment support & $3.89 \pm 0.68$ & $3.16 \pm 0.72$ & 0.73 & 9.95 & 0 & 2.83 & 6 \\
\hline 19 & Overseas training support & $3.94 \pm 0.62$ & $3.07 \pm 0.66$ & 0.87 & 13.06 & 0 & 3.42 & 2 \\
\hline 20 & Language programs & $3.85 \pm 0.71$ & $3.25 \pm 0.64$ & 0.6 & 9.6 & 0 & 2.32 & 8 \\
\hline 21 & Certificate programs & $4.01 \pm 0.63$ & $3.23 \pm 0.65$ & 0.78 & 12.31 & 0 & 3.14 & 3 \\
\hline 22 & Job club support & $3.47 \pm 0.69$ & $3.31 \pm 0.58$ & 0.16 & 2.69 & 0.008 & 0.56 & 19 \\
\hline \multirow[t]{2}{*}{23} & Mentoring & $3.68 \pm 0.71$ & $3.39 \pm 0.69$ & 0.3 & 4.913 & 0 & 1.09 & 14 \\
\hline & & 3.67 & 3.28 & 0.39 & & & & \\
\hline
\end{tabular}

The differences in importance and current level of 23 employment support programs were all statistically significant. Like the two-year university majors, career-related courses, occupational psychology tests, and career path special lecture programs showed higher current levels than importance. Looking at the results of the Borich needs analysis, it was found that the need for field practice programs (3.55) was the highest among employment support programs, and then, needs were high in the order of overseas training support (3.42), certificate programs (3.14), employment information support (3.12), and employment-related courses (3.05). In contrast, the needs for occupational psychology tests $(-1.22)$, career-related courses $(-0.51)$, career path special lecture programs $(-0.41)$, industry field trip programs (0.52), and job clubs (0.56) were found to be low.

Figure 3 shows the results of analyzing the priority of employment support programs using the Locus for Focus analysis. Based on the average of the importance of employment support programs recognized by the 4 -year university majors $($ mean $=3.67)$ and the average of the difference between importance and current level (mean $=0.39)$, nine factors were included in the first quadrant on the coordinate plane, namely, employmentrelated courses, field practice programs, career seminars, mock interviews, employment information support, overseas employment support, overseas training support, language programs, and certificate programs. 


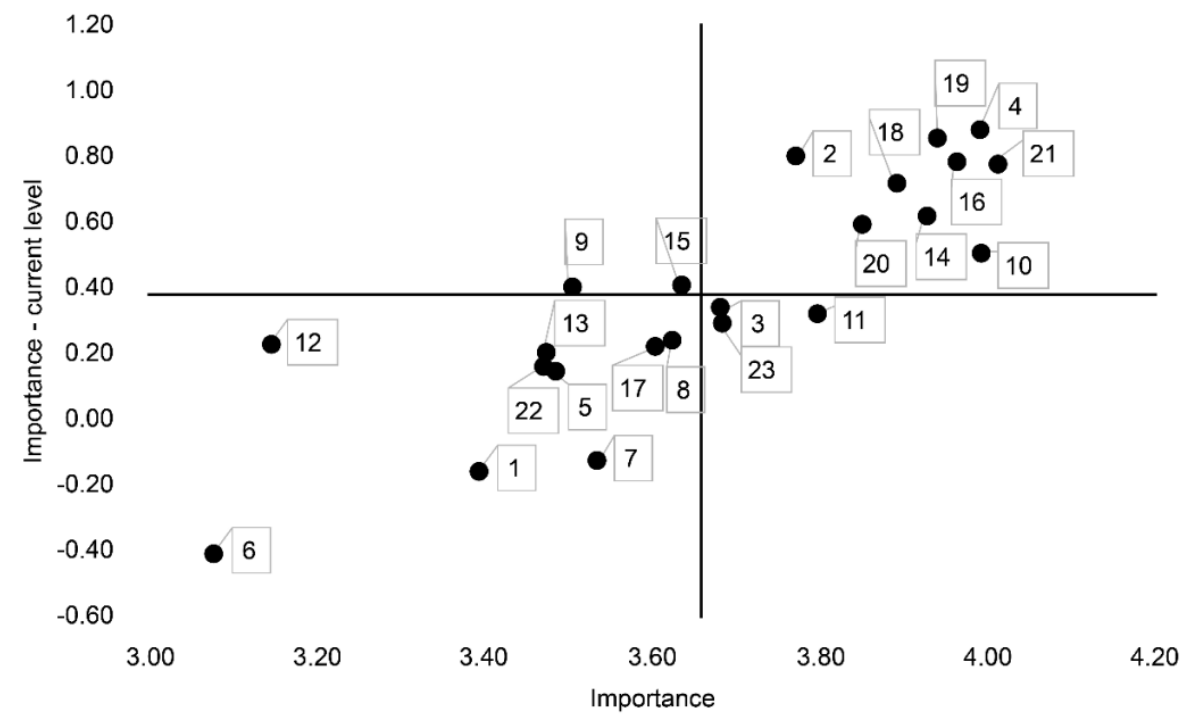

Figure 3. Results of the Locus for Focus analysis for 4-year university students.

\subsection{Analysis of the Highest Priority in Employment Support Programs by School System}

In order to determine the highest priority in employment support programs for hospitality undergraduate students, this study analyzed which programs were located in the first quadrant based on the results of the Locus for Focus analysis, among the programs of education needs that were within the top $50 \%$ based on the study by Cho (2009). The results are shown in Table 4. For 2-year university students, it was found that employment information support, individual career counseling, certificate programs, career seminars, overseas training support, field practice programs, overseas employment support, mentoring, and industry-academic cooperation courses should be applied first. However, mock interviews, language programs, and employment-related courses were ranked in the top $50 \%$ of the Borich needs analysis results, but the Locus for Focus analysis showed that they were located in the 2nd and 3rd quadrants and were not included among the top priorities.

For 4-year university students, it was found that employment information support, certificate programs, career seminars, overseas training support, field practice programs, overseas employment support, mock interviews, language programs, and employmentrelated courses among employment support programs should be prioritized. However, employment camps, career fairs, and industry-academic cooperative courses were ranked in the top $50 \%$ of the Borich needs analysis results, but the Locus for Focus analysis showed that they were located in the 2nd and 4th quadrants and were not included among the top priorities. In addition, individual career counseling, mentoring, and industry-academic cooperation courses, which were the highest priority for 2-year university majors, were not included among the top priorities because they were located in the fourth quadrant as a result of the Locus for Focus analysis. 
Table 4. Results of Borich needs analysis and the Locus for Focus analysis.

\begin{tabular}{|c|c|c|c|c|c|c|c|}
\hline \multirow[b]{2}{*}{ No. } & \multirow[b]{2}{*}{ Program } & \multicolumn{3}{|c|}{ 2-Year } & \multicolumn{3}{|c|}{ 4-Year } \\
\hline & & Rank & LF & $\begin{array}{l}\text { High- } \\
\text { Priority }\end{array}$ & Rank & LF & $\begin{array}{l}\text { High- } \\
\text { Priority }\end{array}$ \\
\hline 16 & Employment information support & 1 & I & $\mathrm{O}$ & 4 & I & $\mathrm{O}$ \\
\hline 11 & Individual career counseling & 2 & I & $\mathrm{O}$ & 13 & IV & \\
\hline 21 & Certificate programs & 3 & I & $\mathrm{O}$ & 3 & $\mathrm{I}$ & $\mathrm{O}$ \\
\hline 10 & Career seminars & 4 & I & $\mathrm{O}$ & 9 & I & $\mathrm{O}$ \\
\hline 19 & Overseas training support & 5 & I & $\mathrm{O}$ & 2 & I & $\mathrm{O}$ \\
\hline 4 & Field practice programs & 6 & I & $\mathrm{O}$ & 1 & I & $\mathrm{O}$ \\
\hline 18 & Overseas employment support & 7 & I & $\mathrm{O}$ & 6 & $\mathrm{I}$ & $\mathrm{O}$ \\
\hline 23 & Mentoring & 8 & $\mathrm{I}$ & $\mathrm{O}$ & 14 & IV & \\
\hline 14 & Mock interviews & 9 & II & & 7 & $\mathrm{I}$ & $\mathrm{O}$ \\
\hline 3 & Industry-academic cooperation courses & 10 & $\mathrm{I}$ & $\mathrm{O}$ & 12 & IV & \\
\hline 20 & Language programs & 11 & II & & 8 & $\mathrm{I}$ & $\mathrm{O}$ \\
\hline 2 & Employment-related courses & 12 & III & & 5 & $\mathrm{I}$ & $\mathrm{O}$ \\
\hline 8 & Employment special lecture programs & 13 & IV & & 15 & III & \\
\hline 12 & Group career counseling & 14 & III & & 18 & III & \\
\hline 9 & Career fairs & 15 & III & & 11 & II & \\
\hline 13 & Résumé writing support & 16 & IV & & 17 & III & \\
\hline 17 & Competition support & 17 & IV & & 16 & III & \\
\hline 15 & Employment camps & 18 & IV & & 10 & II & \\
\hline 22 & Job club support & 19 & III & & 19 & III & \\
\hline 5 & Industrial site tour programs & 20 & IV & & 20 & III & \\
\hline 6 & Occupational psychology tests & 21 & III & & 23 & III & \\
\hline 7 & Career path special lecture programs & 22 & III & & 21 & III & \\
\hline 1 & Career-related courses & 23 & III & & 22 & III & \\
\hline
\end{tabular}

\section{Discussion}

The purpose of this study was to investigate the importance and current level of various employment support programs operated by universities as perceived by university students in the hospitality industry, and to analyze which employment support programs should be supported first. For this, a survey was conducted among 384 students enrolled in hospitality-related departments in universities, and the analysis results are summarized as follows.

First, as a result of analyzing Borich needs, there was a difference in needs between 2-year majors and 4-year majors. In the case of 2-year majors, needs were high in the order of employment information support, career counseling, and certificate programs, and in the case of 4-year majors, needs were high in the order of field practice programs, overseas training support, and certificate programs.

Second, as a result of Borich needs and a Locus for Focus analysis, employment information support, certificate programs, career seminars, overseas training support, field practice programs, and overseas employment support were found to be high-priority programs for both 2-year and 4-year majors.

Third, individual career counseling, mentoring, and industry-academic cooperation courses appeared to be the highest priority programs to support 2-year majors, but in the case of 4-year majors, the differences between the importance and current level of these three programs were not significantly different, indicating that they are relatively well supported by universities. In addition, mock interviews, language programs, and employment-related courses were the top priority programs to support 4-year majors. However, 2-year majors perceived low importance in mock interviews and language programs, and employment-related courses showed that there was little difference between importance and current level.

Based on these analysis results, the implications for employment support programs for hospitality undergraduate students are as follows. First, as in the studies by Lee and 
Kang (2014) and Park et al. (2012), the need for programs such as employment information support, individual career counseling, certificates, career seminars, field practice programs, mentoring, and industry-academic cooperation courses, which can have an immediate impact on hospitality majors in 2-year university students, is high. It is believed that this is due to the fact that 2-year majors have less time to search and prepare for their career path than those in the 4-year system. Therefore, it is necessary to have the students establish career and employment goals through individual career counseling and mentoring programs. In addition, it is necessary to provide support for career preparation, such as obtaining certificates and participating in an internship in a major field before graduation, and through career seminars and industry-academic cooperation courses, employmentrelated information should be continuously provided so that the transition from college to work can be smoothly performed after graduation.

Second, to improve career and employment-related support programs recognized by university students, as in the study by Lee et al. (2019), which showed that activation of internships and recruitment events was the most necessary, this study also showed that the need for internships was the highest priority. This result is thought to be due to the fact that the hospitality industry is not hiring new employees and operating internship programs at the time of the survey due to reductions in personnel resulting from the decline in sales due to COVID-19. In other words, as in the study by Chao and Kim (2016), which claimed that 4 -year university students should find a career that suits them early through internships and prepare for it, universities and departments will need to enable many students to participate in internship programs.

Third, both 2- and 4-year majors showed a large gap between the importance and current level of overseas training, overseas employment support, and language programs. As shown in the study by Ahn and Yim (2018), the language experience and language skills of university students have an effect on the shortening of the employment period, and the study by Kil (2013) showed that students who gained confidence in learning English and increased interest in English-speaking countries after the English camp showed positive responses to overseas employment. To improve the inclination of hospitality majors toward overseas internships or employment, it is necessary to introduce support programs that allow them to participate in overseas training and language programs.

Despite having highlighted these implications, this study has the following limitations. First, since the survey was conducted on hospitality majors attending only some universities in Korea, there is a limit to the use of the research results in all universities. Therefore, based on this study, it is necessary to establish strategies for employment support programs in consideration of the location, size, and characteristics of each university.

Second, the analysis was limited to those who were attending the graduation semester. As a number of preceding studies have shown that there is a difference between the competencies required by companies and the competencies acquired through university education, the gap between these competencies could be reduced by analyzing and comparing the education needs of graduates working in related industries after graduation or by industry human resources managers.

Third, there is a limit to the perspective of the study. In 2020, when this study was conducted, some employment support programs such as employment camps, domestic and international internships, and overseas language training had been canceled or reduced due to the ban on group activity due to the spread of COVID-19 and self-isolation of foreign arrivals. In turn, students may have responded negatively to the current level because there was no experience in participating in each program. Therefore, it will be necessary to analyze and compare the needs of students when COVID-19 has been overcome.

\section{Conclusions}

This study analyzed which employment support programs should be prioritized in making career decisions to improve job landing ability by undergraduate hospitality 
students, who have seriously underperformed in the labor market due to travel restrictions, border closures, and business disruptions amid the COVID-19 pandemic.

Our study, which identified educational needs from the perspective of students participating in employment support programs, showed that employment support programs to be given top priority varied depending on the school year of the students. Therefore, it is necessary for the officials of the universities' employment support programs to continuously identify and support the needs of students rather than providing uniform support across all programs. This study will aid the officials of university employment support programs in developing and implementing programs more efficiently while improving the students' job landing performance in the labor market.

Author Contributions: Conceptualization, T.-K.N. and S.-H.L.; methodology, T.-K.N. and S.-H.L.; validation, T.-K.N. and S.-H.L.; formal analysis, T.-K.N. and S.-H.L.; investigation, S.-H.L.; data curation, T.-K.N. and S.-H.L.; writing—original draft preparation, T.-K.N. and S.-H.L.; writing-review and editing, T.-K.N. and S.-H.L.; visualization, T.-K.N.; supervision, T.-K.N.; project administration, T.-K.N. All authors have read and agreed to the published version of the manuscript.

Funding: This research received no external funding.

Data Availability Statement: The data presented in this study are available on request from the corresponding author. The data are not publicly available due to confidentiality agreements with participants.

Conflicts of Interest: The authors declare no conflict of interest. The funders had no role in the design of the study; in the collection, analyses, or interpretation of data; in the writing of the manuscript, or in the decision to publish the results.

\section{References}

Ahn, So-Youn, and Eun-Soon Yim. 2018. A Study on the Factors Affecting the Employment of Bachelor's in Tourism. Journal of Hospitality and Tourism Studies 20: 15-27. [CrossRef]

Ahn, Jung-Suk, Jae-Hee Im, and Sung-Sik Ahn. 2018. A Study on the Influencing Contextual Factors of College Graduates on the Initial Employment Outcomes in Food Service Management Program in South Korea. Journal of Employment and Career 8: 45-67. [CrossRef]

An, Sim-Yeon. 2018. The Usage of University Employment Support Program and the Effect on the First Job Satisfaction of Graduates Students: Based on Salespersons. Journal of Distribution and Logistics 5: 143-61. [CrossRef]

Aquino, Richard S., Gertrude P. Tuazon, Tyron W. Yap, and Ian Bencio M. David. 2017. In Search of Greener Pastures? Investigating Filipino Tourism and Hospitality Management Students' Willingness to Work Overseas. Asia-Pacific Journal of Innovation in Hospitality and Tourism 6: 81-90.

Bae, Gwang-Min, and Kwang-Sik Yoon. 2015. Training Needs Analysis for The Development of Basic Job Skill Curriculum in Specialized High School. Journal of the Korean Institute of Industrial Educators 40: 44-71. [CrossRef]

Borich, Gary D. 1980. A Needs Assessment Model for Conducting Follow-Up Studies. Journal of Teacher Education 31: 39-42. [CrossRef]

Busby, Graham D., and Philip Gibson. 2010. Tourism and Hospitality Internship Experiences Overseas: A British Perspective. Journal of Hospitality, Leisure, Sports and Tourism Education 9: 4-12. [CrossRef]

Chao, Yun, and Wan-Soo Kim. 2016. The Effect of Previous Work Experiences on Hospitality Undergraduate Students Future Career Intention. Journal of Tourism Studies 28: 107-30. [CrossRef]

Cho, Dae-Yeon. 2009. Exploring How to Set Priority in Need Analysis with Survey. The Journal of Research in Education 35: $165-87$.

Choi, Young-Keun. 2020. A Study on Satisfaction Analysis of Employment Assistance Program in Korean University. Journal of the Korea Management Engineers Society 25: 137-51. [CrossRef]

Choi, Gyeong-Eun, and Hyoung-Jong Kim. 2020. Tourism Market Views According to COVID-19. Korea Tourism Policy 80: 30-38.

Chun, Young-Min, Sung-Cheol Jung, and Ki-Seong Nam. 2019. The Effect of Participation in University Job Support Program on Employment. Journal of the Korean Data Analysis Society 21: 141-51. [CrossRef]

Deale, Cynthia S., and Donald Schoffstall. 2015. Hospitality and Tourism Education and Industry Certifications. Journal of Hospitality $\mathcal{E}$ Tourism Education 27: 112-19. [CrossRef]

Han, Eu-Jin, and Bom-Yung Hwang. 2019. A Study on the Relationship between Major Satisfaction and Employment Stress of University Students: Focusing on Tourism-Related and Health-Related Majors. International Journal of Tourism Management and Science 34: 203-22. [CrossRef]

Jun, Hee-Won. 2013. A Study on Plans for Global Human Resource Development in Hotel and Tourism Sector. Northeast Asia Tourism Research 9: 179-201. 
Jung, Hyun-Kyoung, Yun-Hee Jung, Hye-Sun Lee, and Chang-Gook Youn. 2018. A Study on Types and Effectiveness of Employment Support Programs in Colleges Based on Career Decision-Making Self-Efficacy, Job Seeking Stress, and Employ Ability. The Journal of Learner-centered Curriculum and Instruction 18: 465-87. [CrossRef]

Kaushik, Meenakshi, and Neha Guleria. 2020. The Impact of Pandemic COVID-19 in Workplace. European Journal of Business and Management 12: 9-18.

KEDI (Korean Educational Development Institute). 2020. “OECD Education index 2020." Press release. Available online: https:/ / www.kedi.re.kr/khome/main/announce/selectAnnounceForm.do?currentPage=1\&editor_use_yn=Y\&selectTp=0\& article_sq_no=33706\&board_sq_no=3 (accessed on 9 September 2020).

KERI (Korea Economic Research Institute). 2020. “Youth Unemployment Rate, OECD 4.4\%p Decrease Over 10 Years, Korea 0.9\%p Increase." Press Release. Available online: http:/ /www.keri.org/web/www/news_02?p_p_id=EXT_BBS\&p_p_lifecycle=0\&p_p_

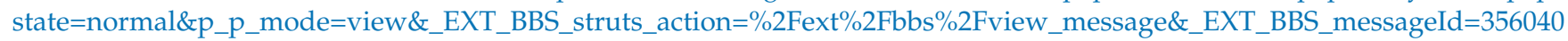
(accessed on 9 September 2020).

KESS (Korean Educational Statistics Service). 2020. “The Latest Educational Statistics." Educational Statistics. Available online: https: / / kess.kedi.re.kr/index (accessed on 11 December 2020).

Kil, In-Suk. 2013. Study on Overseas Employment Motivation of Two-Year Tourism Majors after English Intensive Training. Journal of Tourism Management Research 17: 23-38.

Kim, Nan-Young. 2018. An Exploratory Study on the Employment of University Students in Majoring Tourism. Journal of Tourism Enhancement 6: 203-17. [CrossRef]

Kim, Gun. 2019. The Study of the Effect for Job Preparation Behavior of Hotel Major Student on the Job Decision Factor. Tourism Research 44: 25-41.

Kim, Se-Um. 2020. Policy Direction for Employment Support in Tourism Industry in the Post COVID-19 Era. Korea Tourism Policy 80: $52-58$.

Kim, Young Joong, and Young-Guk Chung. 2018. The Effects of Motivation to Participate in Culinary Competition on the Sense of Psychological Well-Being and Employment Preparation Behavior of Culinary Majoring Students: Focused on Differences Between College and Vocation Training Institute. Culinary Science E Hospitality Research 24: 40-51. [CrossRef]

Kim, Hee-Yeon, Nam-Su Kim, and Heon-Su Ha. 2017. The Effect of Mentoring Function on Learning Commitment and Career Decision: Focusing on Cooking Practice. Journal of Tourism and Leisure Research 29: 351-62.

Kim, Bo-Kyun, Hyo-Sung Lee, and Hong-Beom Kim. 2019. A Study on Determinants of Employment in College Graduates Majoring in Hospitality \& Tourism. Journal of Hospitality and Tourism Studies 21: 61-74. [CrossRef]

Kim, Bo-Gyun, Hyu-Seong Lee, and Hong-Beom Kim. 2020. A Difference Analysis on Job Satisfaction According to English Capabilities of Hotel Employees. Journal of Tourism E Leisure Research 32: 217-36. [CrossRef]

KOSTAT (Statistics Korea). 2020. “Employment Trend in August 2020.” Press release. Available online: http:/ / kostat.go.kr/portal/ korea $/$ kor_nw $/ 1 / 1 /$ index.board?bmode $=$ read\&bSeq=\&aSeq=385035\&pageNo=1\&rowNum=10\&navCount=10\&currPg= \&searchInfo=srch\&sTarget=title\&sTxt=\%EA\%B3\%A0\%EC\%9A\%A9\%EB\%8F\%99\%ED\%96\%A5 (accessed on 9 September 2020).

Lee, Ching-Sung, and Chen-Wei Chao. 2013. Intention to "Leave" or "Stay"-The Role of Internship Organization in the Improvement of Hospitality Students' Industry Employment Intentions. Asia Pacific Journal of Tourism Research 18: 749-65. [CrossRef]

Lee, Hee-Soo, and Sung-Hawe Hwang. 2019. A Study on the Relationship Among the Participant's Motivation, Learning Commitment, Learning Achievement, and Participation Satisfaction of NCS Bartender Job Cocktail Contest Participants. Korean Journal of Tourism Research 34: 205-24. [CrossRef]

Lee, Ji-Won, and Kyung-Hee Kang. 2014. Study about the Relationship between Self-Esteem, Depression and Stress of Students According to School System. Journal of the Korea Convergence Society 5: 69-74. [CrossRef]

Lee, Mi-Na, and Ji-Won You. 2019. Comparison of Career Identity, Job Competencies, Major Satisfaction, and Academic Achievement According to Participation of Undergraduate Research Program in Science Majors. The Journal of Vocational Education Research 38: 99-117. [CrossRef]

Lee, Ji-Eun, Yun-Kyeong Jeong, Hyeon-Mi Rha, and Hae-Kyoung Lim. 2019. A Study on Awareness and Demand Analysis of Undergraduate Student's Career Education for Improvement of University Career Education. The Journal of Employment and Career 9: 55-75.

Lee, Joo-Hyeon, Mi-Kyung Kim, Ye-Jee Cho, and Hye-Kyung Kim. 2020. 2018 Basic Analysis Report of the Graduates Occupational Mobility Survey. Seoul: Korea Employment Information Service, pp. 1-275.

Lim, Jung-Yon, Ji-Young Yoon, and Mi-Sun Kim. 2020. Analysis of the Educational Needs Related to, and Perceptions of the Importance of, Essential Job Competencies among Science and Engineering Graduates. Education Sciences 10: 85. [CrossRef]

Min, Chang-Kee. 2008. A Study on the Foreign Language Learning Competency of Tourism Majors. International Journal of Tourism and Hospitality Research 22: 185-99.

Mink, Oscar G., James M. Shultz, and Barbara P. Mink. 1991. Developing and Managing Open Organizations: A Model and Method for Maximizing Organizational Potential. Austin, TX: Somerset Consulting Group, Inc., pp. 1-284.

Moreo, Andrew, Alison J. Green, and Robert O'Halloran. 2018. What Certifications are Important in the Hospitality Industry? Journal of Human Resources in Hospitality \& Tourism 17: 121-35. [CrossRef]

Oh, Seung-KuK, Jun-Ju Sung, and Yong-Ho Park. 2014. Complementing a Typical Educational Needs Analysis Using a Survey in Setting the Priority of the Needs. The Journal of Research in Education 27: 77-98. 
Park, Mi-Jeong, Young-Lim Ham, and Doo-Nam Oh. 2012. Levels and their Correlations of Decision-Making-Competency, Adjustment to College Life, Satisfaction to College Life in Freshmen. The Journal of the Korea Contents Association 12: 327-37. [CrossRef]

Park, Kwi-Hwa, Young-Hee Lee, Eui-Ryoung Han, Sang-Hee Yeo, Min-Jeong Kim, and Hye-Rin Roh. 2020. An Analysis of Medical Students' Perceived Competencies and Educational Needs for the Coming Age of the Fourth Industrial Revolution. Journal of Education E Culture 26: 979-97.

Scerri, Madalyn, Rajka Presbury, and Edmund Goh. 2020. An Application of the Mentoring Framework to Investigate the Effectiveness of Mentoring Programs between Industry Mentors and Student Mentees in Hospitality. Journal of Hospitality and Tourism Management 45: 143-51. [CrossRef]

Seo, Hwa-Joung, and Byoung-Joo Kim. 2016. Analysis on Structural Relation among Employment Supporting Program, University Educational Satisfaction, Job Satisfaction and Job Match. Korean Journal of Educational Administration 34: 51-75.

Shin, Hye Sook, Byeong-Cheol Min, and Soo-Kyung Nam. 2014. Evaluating the Effect of the Government-Funded Employment Support Program on the Graduates' Employment Outcome. Asian Journal of Education 15: 201-23. [CrossRef]

Song, Yeon Ok. 2020. Analysis of University Freshmen's Perception of Computational Thinking Using Borich Needs and the Locus for Focus Model. Journal of Learner-centered Curriculum and Instruction 20: 437-57. [CrossRef]

Tsai, Chen-Tsang Simon, Hsuan Hsu, and Chun-Chin Yang. 2017. Career Decision Self-Efficacy Plays a Crucial Role in Hospitality Undergraduates‘ Internship Efficacy and Career Preparation. Journal of Hospitality, Leisure, Sport E Tourism Education 21: 61-68. [CrossRef]

Wang, Yao-Fen, Min-Huei Chiang, and Yi-Ju Lee. 2014. The Relationships amongst the Intern Anxiety, Internship Outcomes, and Career Commitment of Hospitality College Students. Journal of Hospitality, Leisure, Sport \& Tourism Education 15: 86-93. [CrossRef]

Youn, Jung-Hye, and Yong-Lim You. 2015. The Study of College Employment Support Programs for College Student's Competence. Korean Journal of Youth Studies 22: 479-504.

Zampoukos, Kristina, and Dimitri Ioannides. 2011. The Tourism Labour Conundrum: Agenda for New Research in the Geography of Hospitality Workers. Hospitality \& Society 1: 25-45. [CrossRef]

Zopiatis, Anastasios, and Antonis L. Theocharous. 2013. Revisiting Hospitality Internship Practices: A Holistic Investigation. Journal of Hospitality, Leisure, Sport $\mathcal{E}$ Tourism Education 13: 33-46. [CrossRef] 